\title{
Concept of Life Skills Based-Adult Education for Housewife
}

\author{
Sri Hapsari, Askardiya Mirza Gayatri, Deden Ibnu Aqil \\ Economic Education \\ University of Indraprasta PGRI \\ Jakarta, Indonesia \\ sri.hapsari@unindra.ac.id
}

\begin{abstract}
The purpose of this research is to improve the housewife life skills through adult education in the region of Bedahan, West Java. This region has sufficient good human resources so that it can contribute to the rural development in the region. The potential of this human capital should be empowered to achieve the objectives of rural development. Adult education based-life skills in the form of vocational education in processing the patchwork waste into products that have a selling value. The stage of this adult education began by raising the public awareness of the importance of treating waste to protect the environment, and entrepreneurship motivation, followed by waste processing skills, mentoring of independent creation of products, as well as online promotional strategies.
\end{abstract}

Keywords-adult education, life skill, village development, entrepreneurship

\section{INTRODUCTION}

Indonesia has a blessed demographic and its human capital is potential in the international market. However, it would be a catastrophe if the human capital is not equipped with life skills. Indonesian people who are still dominated by the female sex must get attention from related parties because of their role as a wife and a mother. Nowadays, it is a dilemma for a woman who plays a double role, as a wife, a housewife, and a worker. Many of them fill the spare time on the sidelines of the daily routine as a mother and a wife [1]. The reason they work other than to develop themselves is also to overcome the problem of the household economy in order to have income or own source of income to cover the inadequate financial shortage if they only rely on the husband's income as head of the household.

West Java has potential human capital that needs to be empowered as well as socio-economic diversity. The diversity of natural resources, human resources, geography, history, and culture of each region is an asset of nation-building [2]. Human capital is supported by the high motivation to learn among housewives. Learning is not determined by age. One of the problem-solving is to empowerment through skill training, especially for housewife to be independent and develop themselves by exploring their potential. Learning does not consider the age. Learning is seen as a process to gain knowledge, improve skills, behavior, and attitudes, as well as strengthen personality [3]. Learning materials can be skills
Empowerment means powering or sharing the power with someone because they are powerless or they do not have any power, so it almost does not do anything [4]. Generally, empowerment is done through training. Appropriate skills training for housewives should be close to their daily life, the home environment.

In Bedahan, West Java, there are some people who work as tailors as well. Of course, this waste material is very potential to be used as goods or products with high economic value when it is creatively handled by craftsmen. Increasing business actors in the field of waste processing makes the competition between business actors very tight so that the business actors have to make a strategy for reviewing their products to be accepted by the market, because consumers generally want innovative products according to their reviews [5]. So, in this training participants can create various forms of products, as community service teams realize that product innovation development must be planned.

With this empowerment, they are expected to be able to have a life skill. It is the ability of having adaptive and positive behaviors, allowing individuals to effectively deal with the demands and challenges of everyday life [6]. It is not only they earn additional income from the selling of the products but It is also the efforts are made as part of preserving the environment. Life skill also means a broad knowledge and interaction of skills considered as essential needs for humans to live independently [7].

Based on the above background, the adult education based on life skills are appropriate to be given to the housewife. Adult education is an approach to adult learning, emphasizing on the learning techniques for adult people so they are able to and willing to learn in accordance with the objectives to be achieved [8].

\section{RESEARCH METHODS}

This study used a descriptive approach, a systematic and factual description. This study provides an overview of the activities in the community development processing rag waste into economically valuable products. The target in this study was the housewife in Bedahan, West Java. Life skills-based education was given so that people were courage and willing to naturally face the life problems and life without feeling pressured, and proactively and creatively find a solution so that 
eventually they can overcome the problems [9]. The stages of adult education based on life skills are as follows:

The first stage is the public awareness to protect the environment, the material is about the waste of the patchwork and the other household wastes and their impacts on the environment. It is followed by the extension in managing household waste through the2R (Reduce and Reuse) motions.

The second stage is providing entrepreneurial materials for housewives. In this material, the participants are given the knowledge how to explore the potential and develop the surrounding raw materials that can be an economic value so as to create business opportunities. There are several stages to be an entrepreneur: (1) the starting-up, (2) doing business, (3) maintaining a business, (4) developing business [10]. Because the participants were quite enthusiastic in this material, they were also given some examples of entrepreneurs who started their business from scratch. With this entrepreneurial material, the participants are expected to be motivated in starting a business.

The third stage is the skill to make handicrafts using patchwork, become various accessories, such as brooches, placemat, necklaces, bracelets, and rings. Fig1 provides the training documentation.

The fourth stage was the online marketing strategy. It means the community devotion team of patchwork trained the marketing of products by online marketing. The strategy is considered to reach wider consumers, relatively cheap, and easy to use.

The fifth stage was independent skill. After the motherhousewife created accessories using basic skills, then they independently made a number of accessories, and could sell these accessories by online marketing. The fifth stage of this education formed a person's life skills of regarding the changes not only in cognitive, but also in the affective, and psychomotor aspects, because the life skills do not only provide the insight but through the experience of living in the form of individual activities as well as joint and performed continuously [11].

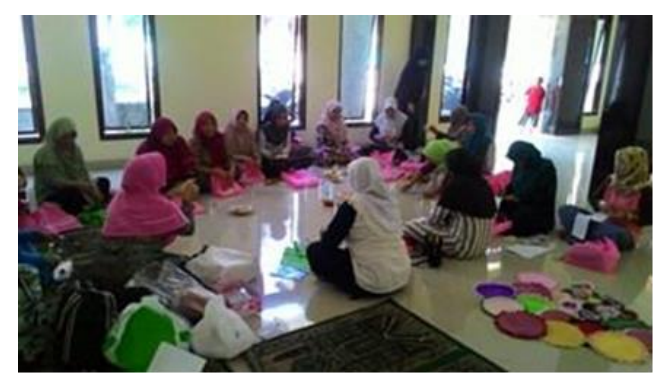

Fig. 1. Training to Make Placemat

\section{CONCLUSION}

Adult education based on life skills involves the motherhousewife. Life skills are the ability to build attitudes, mental, and positive competence to face the realities of life. The concept is to provide skills education in processing waste into products that can be sold and boost family income to sustain in life. The results showed that the program aimed to build life skills could improve the social behavior, ability to plan ahead, choose effective solutions to exploit the potential of the environment, and adjust to the environment.

\section{ACKNOWLEDGMENTS}

Our thanks to Kemenristekdikti (The Ministry of Research and Higher Education) for in 2017, we received lecturer of Indraprasta PGRI University by Letter Contract Number: 0621 / SKP.PPM / LPPM / UNINDRA / VI / 2017 so that the team can implement the life skills education in West Java.

\section{REFERENCES}

[1] P. Pratiwi, Peluang Bisnis untuk Ibu Rumah Tangga. Yogyakarta: Tugu Publisher, 2010.

[2] A. Santoso, A. Setyowati, and M. Nurmilawati, "Pembangunan Karakter melalui Lesson Studi pada Pendidikan Lingkungan Hidup Berbasis Keunggulan Lokal,” in Prosiding Semnas VIII Biologi vol. 8 (1), 2011.

[3] S. Suyono and M. Haryanto, Belajar dan Pembelajaran. Bandung: Remaja Rosdakarya, 2011.

[4] S. Marzuki, Pendidikan Non Formal. Dimensi dalam Keaksaraan Fungsional, Pelatihan, dan Andragogi. Bandung: PT Remaja Rosdakarya, 2010.

[5] A. Octavia, E. Erida, S. Sumarni, and I. Sam, "Pelatihan Kewirausahaan dan Manajemen bagi Ibu Rumah Tangga, Remaja Putri, dan Kelompok Usaha Bersama Mutiara Kota Jambi," J. Pengabdi. Pada Masy., vol. 31, no. 3, pp. 36-41, 2016.

[6] Y. Yokhebed, T. Titin, and E. S. Wahyuni, "Peningkatan Life Skill melalui Pembelajaran berbasis Keunggulan Lokal,” in In Proceeding Biology Education Conference: Biology, Science, Enviromental, and Learning, 2016, pp. 455-460.

[7] D. Sumirat, "Life Skill Bidang Penyiaran Satu Solusi Atasi Pengangguran.," Gemari, 2007.

[8] S. Sunhaji, "Konsep Pendidikan Orang Dewasa," J. Kependidikan, vol. 1, no. 11, pp. 1-11, 2013.

[9] N. ( Aznam, "Implementasi Life Skill pada Pembelajaran Kimia Bahan Aditif," J. Cakrawala Pendidik., vol. 2, no. 2, pp. 166-179, 2002.

[10] S. Hapsari and S. Dhova, "Pendidikan Kewirausahaan di Lapas dengan Pendekatan Minat Usaha,” J. Visi, vol. 9, no. 1, pp. 47-55, 2014.

[11] S. Listyaning, "Pendidikan Kecakapan Hidup (Life Skills) Melalui Child Friendly Teaching Model (Cftm) Sebagai Dasar Membangun Karakter Siswa," E-DIMAS, vol. 3, no. 1, 2012. 